\title{
東海地方における移住労働者のエスニシティ構成の「逆転現象」 静岡県焼津市の水産加工労働者の事例— \\ The Replacement Phenomenon of the Ethnic Composition of Migrant Workers in the Tokai Region, Japan:
}

A Case Study of Fish Processing Workers in Yaizu City, Shizuoka Prefecture

\author{
高畑 幸
}

\section{Sachi TAKAHATA}

This study aims to clarify the reorganization of ethnic compositions in industrial cities of the Tokai Region, Japan, during the late 2000s. After the global financial crisis in late 2008, Brazilian Nikkei workers returned to their homeland after losing their jobs while the number of Filipino Nikkei workers in the region increased. Filipino Nikkei replaced Brazilian workers in the manufacturing industry following the economic boom of 2013. This "replacement phenomenon" of Brazilians by Filipinos was observed in several municipalities. The author conducted field research in Yaizu City, Shizuoka Prefecture, and Davao, Philippines. People involved in the migration system and selected Nikkei workers were interviewed for the study, which revealed that certain occupations and "spaces" always required Nikkei workers who could remain in Japan for extended periods of time because of their privileged residential status. Findings include: (1) the increase in Filipinos in Japan since the 2010s is largely due to chain migration by clans whose Nikkei identity had been legally established; (2) the migration system in both countries bridged employers and workers in that manpower agencies lent travel costs to Nikkei newcomers, which establish residential enclaves within Japan; (3) compared with Filipino marriage migrants, Nikkeis live with their own relatives, thus forming ethnically concentrated residential enclaves; (4) in contrast to Brazilians who opened their own schools right after a mass migration to Japan in the 1990s, Filipino children attending Japanese schools experienced a more serious "adjust-or-go-home" situation in terms of education.

\section{1. はじめに}

本稿の目的は、日本の地域社会におけるエスニシティ構成の再編を明らかにすることに ある。東海地方の工業都市では、2008年末のリーマンショックにより南米出身の日系人が 失職し多くの帰国者が出た。しかし、その後 2013 年からのアベノミクスで労働力需要が 
発生しても彼（女）らは日本に戻らず、その「空席」にフィリピン日系人が流入すると同 時に技能実習生の受入れが拡大した。全国的に見ると、国籍別外国人数では 2011 年まで ブラジル人が 3 位でフィリピン人が 4 位だったが、翌 2012 年にその順位は逆転した。そ の後もフィリピ人の増加は続く [在留外国人統計 $]$ 。自治体レベルでは、事例の静岡県焼 津市のように第一位を占めていたブラジル人の位置がフィリピン人に置き換わったところ さえある。本稿ではこれらの自治体を「逆転都市」と呼ぶ。なぜ、このような「逆転」が 特定の都市で起きたのか。結論を先取りすれば、人材派遣会社によるフィリピン日系人の 大量雇用と社員アパートでの居住、それを起点とする呼び奇せ家族の近隣居住が原因で あった。

本研究の問いは以下の 4 点である。第一に、東海地方でフィリピン人が増えた経緯は何 か。第二に、フィリピン人集住地区の形成過程はどのようなものか。第三に、フィリピン 人結婚移民と比較しての、フィリピン日系人の定住と生活課題は何か。第四に、ブラジル 日系人と比較しての、フィリピン日系人の定住と生活の課題は何か。

なお、本稿でいう逆転都市（4市 1 区）の基幹産業は、静岡県焼津市の夕が漁業・水産 加工業で、それ以外は自動車関連産業である。本稿では、産業面では例外的であるものの リーマンショックの前後での「逆転」が最も顕著な焼津市について報告し、他都市につい ては今後、別稿で論じることにしたい。以下では、文献と統計資料に加え、国内の逆転都 市である 4 市 1 区 (2014年〜現在) およびフィリピンのミンダナオ島ダバオ市周辺とマニ ラ首都圈におけるフィールドワーク（1995年から 2017 年に計 4 回）、そして焼津市で 2014 年10月より継続中の定点観測をもとに考察したい。

\section{2. 先行研究}

本研究に関わる先行研究は、(1)リーマンショック後の日本における外国人の居住、(2)フィ リピンの日系社会、(3)水産加工業の外国人労働者、の三分野にある。

第一に、リーマンショック後の外国人居住についてみていく。石川・竹下・花岡による 2010 年国勢調査デー夕の分析によると、2005年から 2010 年に新規来日した外国人の目的 地選択は就労目的で、ブラジル人もフィリピン人も来日後すぐに工業都市で居住している という。逆に、結婚による目的地選択はほぼ無く、近年は製造業に従事するブラジル人 およびフィリピン人の労働者数が結婚移民数を大きく上回っている [石川・竹下・花岡 2014]。これはマクロデータ (国勢調査) の分析から得られる知見であり、今後は地域レベ ルでの実態調査が必要であろう。また、ブラジル人は日本での居住が長期化しながらも非 正規雇用のままであり、その階層が固定化することが懸念されている [樋口 2011 ; 渡戸 2017]。日系人の派遣労働者は南米系が多数だったところフィリピン人が増え、今後は労 働市場でエスニシティ間の「競合」が発生する可能性を注視する必要があろう。 
第二に、フィリピンの日系社会について。後述のように、戦前の日本人移民の子らが、 反日感情が渦巻く戦後をフィリピンで生き延びた。1990年の入管法改正により三世が日本 で就労機会を得た後の「出稼ぎ景気」と、戸籍に未記載の二世たちの国籍回復運動に関す る研究がある [大野 2007 ; 大野 2009 ; Fresnoza-Flot 2008]。また、日本への帰還後の日 系人ついては、かつて母国フィリピンでは差別対象だつた祖先を肯定する言説があること [Vilog 2015]、働き盛りの三世が来日して働き、フィリピンでは中高年の二世が孫 (四世) の面倒を見る「中抜き現象」が起きていることが指摘されている [飯島・大野 2010］。飯 島・大野 [2010］は「フィリピン日系人は日本の地域社会において不可視的存在である」 としているが、静岡県浜松市では親族の近居による小規模集住地区（30４0人）が見られ [高畑 2016]、今後は彼（女）らの地域社会へのインパクトについて考察する必要があるだ ろう。

第三に、水産加工業の外国人労働者については、漁業経済学者による論考が数多く出さ れてきた。水産加工業には中小企業が多いことから大規模な設備投資や生産拠点の海外移 転をする資金力がない。そのため、従来は農家の出稼ぎや近隣の主婦によるパート労働に 頼っていた。しかし、日本人労働者の高齢化による絶対的な労働力不足で外国人労働者の 雇用は不可避であること [加瀬 2005]、外国人労働者の受入れ後は地域住民との交流が必 要であること [増井 2012] が指摘されている。また、特定地域を対象とした研究に金ほか [2017] がある。茨城県大洗町での外国人労働者は、1980年代は超過滞在者、1990年代後 半からインドネシア日系人、2000年代から技能実習生、2010年代以降は日本語学校の留学 生のアルバイトへと変わってきたという [金ほか 2017］。このような変遷は水産加工業に 特徵的なのか、また都市の主要産業の違い（自動車／水産加工）により彼（女）らの定住の ありかたに差異が見られるかを、今後は比較検討する必要があるだろう。

以上をまとめると、ブラジル日系人 (特に自動車製造業に従事) の定住に関する先行研 究は多数ある。また、特定地域での外国人労働者の国籍と在留資格の変化 (日系人 $\rightarrow$ 技能 実習生）に関する研究はあるものの、日系人労働者の出身地の変化 (ブラジルーフィリピ ン）に関する先行研究は見当たらない。そこで本報告では、自動車関連以外の産業が立地 する都市を対象とし、かつ日系人の出身地の変化に焦点を当てていきたい。

\section{3. 属性要因で来日するフィリピン人の変容 : 結婚移民から日系人へ}

\section{1 属性要因で定住するフィリピン人}

2016 年末現在、在日フィリピン人は 243,662 人（女性比率 $72.7 \%$ ) であり、在留資格は永 住 $(124,477$ 人)、定住 $(47,663$ 人)、日本人の配偶者等 $(26,687$ 人) の順で、属性要因で長期 滞在可能な在留資格を持つ人びとが合計 $81.6 \%$ にぼる [在留外国人統計]。

属性要因によるフィリピン人定住者は 3 つに類型化できる。第一に、結婚移民である。 
1980 年代後半から興行労働者 (エンターテイナー) として来日した女性たちが客の日本人 男性と結婚し各地で定住した。1993年から 2015 年に発生した日比国際結婚は合計約 15 万 件にのぼるが、2006年の約 12,000 件をピークとして減少し、2015年は3,000 件余となつた [人口動態統計］。法務省令により 2005 年から興行労働者の受入れ基準が厳しくなり入国 者数が急減したためである。第二に、フィリピン日系人である。2000年代から大家族での 帰還が進んだ (詳細は後述)。第三に、新日系人である。かつて興行労働者の女性と日本 人男性との間に生まれてフィリピンで暮らしていた婚外子とその母親が日本へ帰還してい る。改正国籍法施行により、2009年から 2014 年にかけて 3,548 人が生後認知により日本国 籍を取得した ${ }^{1)}$ 。子どもが 15 歳以下の場合は養育者としてのフィリピン人母に定住資格が 与えられるが、母子世帯のため、大家族の日系人と比べると来日数は小規模である。

日比国際結婚は2006年を境に減少したにも関わらず、属性要因で滞在する在日フィリ ピン人数は増加している。その背景にあったのが日系人の家族移住だと言えよう。以下で はフィリピン日系人の歴史を振り返った後、東海地方での逆転現象に論を進める。

\section{2 フィリピン日系人の歴史}

まず、早瀬 [1989] および大野 [1991，2006］に依拠してフィリピン日系人の歴史につい て確認しておきたい。1903年、アメリカ統治下のフィリピンで首都マニラからルソン島北 部にある避暑地バギオにつながる道路工事に日本人労働者が雇用されたのが、日本からの 第一次移住者集団であった。そして 1910 年、沖縄出身の太田恭三郎がミンダナオ島のダ バオで麻農園開発を始めた。そこで働くため、沖縄、福島、熊本、福岡、山口、広島、鹿 児島等からの移住者が相次ぐ。特に熱帯性気候に慣れた沖縄からの移住労働者が多かつた [大野 2006]。なかには現地の女性と結婚して家庭を築き、土地を取得して農園経営を始 める者もいた。しかし、麻農園は山中にあり日本領事館から遠いため、出生登録がないま ま成長する二世も多かった。戦前、フィリピン全土での日系社会は約 3 万人で、そのうち ダバオで最多の約 2 万人が暮らしていた ${ }^{2)}$ 。日米の戦場となつたフィリピンでは戦後に一 世が強制送還され、現地に残留した妻と二世は反日感情の時代に差別を受け、身元を隠し て山中で困窮生活を送った。日系社会が解体し、戸籍に未記載の二世が多く残された。そ のため、二世以降に日本語や日本文化が継承されることは極めて稀だつた。南米に比べて フィリピンの日系人はより剥奪的状況にあり、戸籍に未記載だったことで、彼（女）らが 日系人として日本へ帰還・出稼ぎを開始する時期が遅れたのである。

\section{3 日系人の「帰還」と出稼ぎ}

次に、大野 [2007］およびOhno［2015］を参照しつつ1956年の日比国交回復から 2000 年 代の日本への帰還までをみていく。ダバオに残留した二世たちが帰還し出稼ぎをする端緒 は引揚者との交流にあった。1970年代になると日本から引揚者や遺族が慰霊団を結成して 
ダバオを訪問し、引揚者と残留二世が再会を果たす。彼（女）らは戦前、日本人小学校で ともに学んだ友人同士である。引揚者が仲介して残留二世が日本にいる一世 (父親) と連 絡を取り、日系人の証明となる戸籍を探すことができた。その後、1980年にダバオで日系 人会が設立され、1990年の改正入管法施行により日系三世が定住資格を得ると、出稼ぎ を目的とした戸籍探しがさらに活発化した。一方、日系人の雇用を希望する日本の企業経 営者が 1992 年、日本フィリピン企業協議会を設立した。初期の会員にはダバオからの引揚 者も含まれていた。日系人は大変貧しかったため、雇用者が渡航費を貸付けて来日させ、 給与から天引きして返済させる方法が一般的であった。一種の移民産業 [GammeltoftHansen and Sorensen 2013] である。

その後、戸籍探しが本格化するのが 2003 年のNPO法人フィリピン日系人リーガルサ ポートセンター設立からである。日比両国に事務所を持つ同センターによると、2017年 5 月時点で戸籍に記載されている二世が 1,058 人おり ${ }^{3)}$ 、その子孫が日本へ帰還し働いてい る。また同センターは日本財団の支援を受けて 2006 年から「就籍プロジェクト」を始め た。フィリピン駐在の職員が戸籍未記載の二世に聞き取りを行って状況証拠を集め、日本 では弁護士が家庭裁判所で就籍を申し立てる ${ }^{4)}$ 。こうして新たに戸籍を得た二世が 2017 年 9 月現在 200 人にのぼつた ${ }^{5)}$ 。

\section{4.フィリピン人の居住の変容 : 過疎地での散在から工業都市での小規模集住へ}

\section{1 過疎地・離島}

日本においてフィリピン人は散在居住が特徵であった。1980年代後半に行政主導の集団 見合いにより過疎地に来た「農村花嫁」や、各地での興行労働を経て地元の男性と結婚し た女性たちがいるからである。その事実は、自治体の外国人総数にしめるフィリピン人比 率 (2016年) によく現れている。フィリピン人比率が高いのは、過疎地（福島県双葉郡葛 尾村、奈良県吉野郡上北山村、山口県熊毛郡上関町、宮崎県東臼杵郡椎葉村、いずれも 100\%) および離島（沖縄県宮古郡多良間村、鹿児島県大島郡喜界町、鹿児島県大島郡天城 町、沖縄県伊平屋村、いずれも $80 \%$ 台）であり、これら自治体には外国人が少ない（1人 〜 40 人台)。日本の周辺部に行くほど地域に根付いたフィリピン人女性の存在感が強い。 同時に、上記の過疎地では 2000 年代以降の新規流入が極めて少ない。

\section{2 東海地方の工業都市}

一方、外国人の多い都市でフィリピン人の割合が高まつているところがある。フィリピ ン人が 500 人以上、かつ外国人人口にしめるフィリピン人比率が高い自治体は、三重県松 阪市 $(58.7 \%)$ 、静岡県駿東郡清水町 $(51.8 \%)$ 、愛知県蒲郡市 $(45.7 \%)$ 、岐阜県可児市 (45.7\%)、静岡県浜松市浜北区 $(41.7 \%)$ 、岐阜県美濃加茂市 $(39.8 \%)$ 、静岡県焼津市 
(39.3\%) の順となる【表 1】。このうち、2006年と 2016 年の間にブラジル人とフィリピン 人が逆転している上位 5 都市が、フィリピン人比率が高い順に松阪市、蒲郡市、可児市、 浜松市浜北区、焼津市であった ${ }^{6)}$ 。なお、逆転が起きた時期は松阪市 (2007 年)、蒲郡市 （2009年）、焼津市 (2012 年)、浜松市浜北区 (2013年)、可児市 (2014年) の順であり、「逆 転現象」の時期とありようは一律ではないことがわかる【表 2】。

表 1 フィリピン人が500人以上かつ比率が高い自治体（上位 20）

\begin{tabular}{|c|c|c|c|c|c|c|c|c|c|c|c|c|c|c|}
\hline & 市 区 & 町 村 & & 総 数 & 中 国 & 韓 国 & $\begin{array}{l}\text { フィリ } \\
\text { ピン }\end{array}$ & $\begin{array}{l}\text { フィリピ } \\
\text { ン比率 }\end{array}$ & ベトナム & ブラジル & ネパール & 米 国 & 台 湾 & その他 \\
\hline 1 & 三重県 & 松阪市 & & 3,971 & 610 & 240 & 2,331 & $58.7 \%$ & 195 & 201 & 10 & 34 & 10 & 340 \\
\hline 2 & 静岡県 & 駿東郡 & 清水町 & 1,077 & 60 & 36 & 558 & $51.8 \%$ & 45 & 163 & 6 & 6 & 6 & 197 \\
\hline 3 & 愛知県 & 蒲郡市 & & 2,571 & 349 & 50 & 1,176 & $45.7 \%$ & 155 & 376 & 23 & 3 & 12 & 427 \\
\hline 4 & 岐阜県 & 可児市 & & 6,618 & 410 & 212 & 3,027 & $45.7 \%$ & 123 & 2,542 & 12 & 15 & 28 & 249 \\
\hline 5 & 静岡県 & 浜松市 & 浜北区 & 1,935 & 209 & 78 & 806 & $41.7 \%$ & 83 & 543 & 14 & 9 & 3 & 190 \\
\hline 6 & 岐阜県 & 美濃加茂市 & & 4,733 & 277 & 80 & 1,885 & $39.8 \%$ & 177 & 2,119 & 9 & 5 & 5 & 176 \\
\hline 7 & 静岡県 & 焼津市 & & 3,591 & 479 & 107 & 1,410 & $39.3 \%$ & 162 & 786 & 34 & 18 & 7 & 588 \\
\hline 8 & 岐阜県 & 土岐市 & & 1,691 & 239 & 237 & 640 & $37.8 \%$ & 86 & 193 & 7 & 7 & 5 & 277 \\
\hline 9 & 岐阜県 & 瑞穂市 & & 2,036 & 563 & 122 & 716 & $35.2 \%$ & 197 & 219 & 16 & 4 & 8 & 191 \\
\hline 10 & 広島県 & 尾道市 & & 2,483 & 424 & 122 & 865 & $34.8 \%$ & 369 & 55 & - & 17 & 30 & 601 \\
\hline 11 & 茨城県 & 日立市 & & 1,727 & 418 & 202 & 592 & $34.3 \%$ & 52 & 24 & 34 & 43 & 20 & 342 \\
\hline 12 & 千葉県 & 市原市 & & 5,181 & 838 & 735 & 1,646 & $31.8 \%$ & 214 & 359 & 64 & 52 & 93 & 1,180 \\
\hline 13 & 茨城県 & 古河市 & & 2,909 & 444 & 173 & 888 & $30.5 \%$ & 260 & 205 & 31 & 18 & 62 & 828 \\
\hline 14 & 埼玉県 & 狭山市 & & 2,166 & 493 & 190 & 649 & $30.0 \%$ & 126 & 165 & 19 & 45 & 42 & 437 \\
\hline 15 & 福岡県 & 久留米市 & & 3,411 & 771 & 257 & 1,015 & $29.8 \%$ & 599 & 57 & 310 & 49 & 24 & 329 \\
\hline 16 & 静岡県 & 沼津市 & & 3,695 & 716 & 383 & 1,060 & $28.7 \%$ & 267 & 222 & 27 & 76 & 60 & 884 \\
\hline 17 & 広島県 & 呉市 & & 3,188 & 596 & 328 & 872 & $27.4 \%$ & 562 & 441 & 8 & 42 & 3 & 336 \\
\hline 18 & 静岡県 & 御殿場市 & & 1,969 & 249 & 163 & 528 & $26.8 \%$ & 56 & 508 & 10 & 20 & 53 & 382 \\
\hline 19 & 愛知県 & 安城市 & & 6,552 & 1,015 & 322 & 1,729 & $26.4 \%$ & 393 & 2,117 & 63 & 17 & 76 & 820 \\
\hline 20 & 愛知県 & 刈谷市 & & 4,290 & 984 & 299 & 1,124 & $26.2 \%$ & 389 & 800 & 49 & 31 & 38 & 576 \\
\hline
\end{tabular}

出典：在留外国人統計（2016年末現在）

表 24 市 1 区の比較 (2016年末現在)

\begin{tabular}{|l|l|r|c|c|c|c|c|c|c|c|c|c|c|}
\hline & & 総人口 & $\begin{array}{l}\text { 外国人 } \\
\text { 数 }\end{array}$ & $\begin{array}{l}\text { 外国人 } \\
\text { 比率 }\end{array}$ & $\begin{array}{l}\text { 外国人集 } \\
\text { 住都市会 } \\
\text { 議の加盟 }\end{array}$ & $\begin{array}{l}\text { フィリピ } \\
\text { ン人数 }\end{array}$ & $\begin{array}{l}\text { フィリピ } \\
\text { ン割合 }\end{array}$ & $\begin{array}{c}\text { ブラジル } \\
\text { 人数 }\end{array}$ & $\begin{array}{l}\text { ブラジル } \\
\text { 割合 }\end{array}$ & $\begin{array}{l}\text { 逆転し } \\
\text { た年 }\end{array}$ & $\begin{array}{l}2007 \text { 年 } \\
\text { からの外国人の } \\
\text { 増加率 }\end{array}$ \\
\hline 1 & 就労先 & 派遣会社 \\
\hline 2 & 蒲郡市 & 80,886 & 2,571 & $3.2 \%$ & $\times$ & 1,176 & $45.7 \%$ & 376 & $14.6 \%$ & 2009 & $228.8 \%$ & 自動車 & $\mathrm{D}$ 社 \\
\hline 3 & 可坚市 & 101,529 & 6,618 & $6.5 \%$ & $\bigcirc \rightarrow \times$ & 3,027 & $45.7 \%$ & 2,542 & $38.4 \%$ & 2014 & $194.5 \%$ & 自動車 & $\mathrm{C}$ 社 \\
\hline 4 & 浜松市浜北区 & 98,254 & 1,935 & $2.0 \%$ & $\bigcirc$ & 806 & $41.7 \%$ & 543 & $28.1 \%$ & 2013 & $158.3 \%$ & 自動車 & B 社等 \\
\hline 5 & 焼津市 & 141,338 & 3,591 & $2.5 \%$ & $\times$ & 1,410 & $39.3 \%$ & 786 & $21.9 \%$ & 2012 & $498.2 \%$ & 水産加工 & $\mathrm{A}$ 社 \\
\hline
\end{tabular}

出典 : 外国人数は在留外国人統計。総人口、主要産業は各自治体のウェブサイト。派遣会社は現地調査による。 注：焼津市は 2008 年に旧・大井川町と合併し、翌年に外国人総数が 777 人増加した。 


\section{3 「逆転現象」の背景}

なぜ、これらの都市でフィリピン人が増えたのだろうか。おおまかに言えば、そこには 派遣労働という雇用形態の限界が示されている。雇用者側はより安く働く「弱者」を求 め、ブラジル日系人より 10 年遅れて来日したフィリピン日系人は、その「求める人材」像 に合致したのである。まず、「逆転都市」では 1990 年代からブラジル日系人が多数働いて いた。2000年代前半、規制緩和により製造現場では派遣労働が常態化する。その後、2008 年末のリーマンショックで多数の南米系外国人が失職し、彼（女）らには「帰国後 3 年間 の再入国禁止」を条件に帰国費用を政府が援助する帰国支援事業が行われた ${ }^{7)}$ 。しかし、 これは南米出身の日系人のみが対象だったため、帰国費用がないフィリピン日系人は失職 しても日本に残留した ${ }^{8)}$ 。一方、前述のように1990年代から日比間の日系人労働者送出／ 受入れルートは確立しており、さらには 2000 年代から日系人の戸籍探しと就籍が進んだ [大野 2007]。こうして日比間には派遣会社による渡航費貸付・就労斡旋が継続すると同 時に親族内の相互扶助（渡航費貸付）による連鎖移動も進んでいたところ、2013年以降に 製造業で人手不足となる時期に、日本に戻るブラジル日系人は限られ、フィリピン日系人 の雇用が拡大した。

この帰結は教育現場にも現れた。2009年に始まつた「虹の架け橋事業」(文科省・国際 移住機関）は当初、ブラジル人の失職・帰国に伴う南米系外国人学校の閉鎖で日本の学校 へ転校する子どもの救済策として、6か月の日本語指導が行われた。事業実施期間の 2009 年から 2014 年、日本各地で合計 8,751 人の子どもたちが日本語指導を受けた。利用者の母 語別統計を見ると、2009年はポルトガル語話者が 7 割だったのが、最終年度の 2014 年は ポルトガル語とタガログ語の母語話者がそれぞれ 3 割となったのである [国際移住機関 2015]。この時期に日本の学校に入るフィリピン人の子どもたちが増えたことがうかがわ れる。同様の傾向が焼津市でも見られた。

\section{5. 静岡県焼津市の事例}

\section{1 焼津市の産業と外国人労働者}

まず、調査地である静岡県焼津市について産業を中心にみていこう。焼津市は漁業が基 幹産業である。昭和 30 年代に遠洋漁業（カツオ・マグロ）の基地となり、2016年末現在、 年間水揚げ量は 16.9 万トン、年間水揚げ高は 441 億円で、いずれも千葉県銚子市に次いで 全国2位である。同市の業種別製造出荷額の 4 割が食料品で、その多くを水産加工品がし める。主力は節製品（かつおぶし、なまりぶし等）である [2016末現在、統計やいづ ${ }^{9) 。}$ 市の住民基本台帳人口は日本人 137,894 人、外国人 3,444 人であり、外国人比率 $2.5 \%$ とな り全国平均を上回る。外国人住民の国籍別では、フィリピン $(1,364$ 人)、ブラジル $(745$ 人)、中国 $\left(458\right.$ 人)、ペルー $\left(189\right.$ 人) の順に多い [2016末現在、統計やいづ］【表 $3 \rrbracket^{10)}$ 。 
表 3 焼津市の外国人数 (2007-2016)

\begin{tabular}{lrrrrrrrrrr}
\hline & 2007 & 2008 & 2009 & 2010 & 2011 & 2012 & 2013 & 2014 & 2015 & 2016 \\
\hline フィリピン & 274 & 309 & 641 & 682 & 800 & 922 & 1,003 & 1,129 & 1,177 & 1,364 \\
ブラジル & 1,119 & 1,105 & 1,219 & 1,084 & 973 & 866 & 763 & 709 & 712 & 745 \\
中国 & 517 & 578 & 799 & 784 & 688 & 603 & 579 & 543 & 503 & 458 \\
ペルー & 217 & 215 & 257 & 223 & 225 & 207 & 193 & 186 & 179 & 189 \\
韓国・朝鮮 & 152 & 151 & 158 & 162 & 150 & 149 & 151 & 134 & 126 & 119 \\
米国 & 15 & 14 & 23 & 22 & 20 & 19 & 16 & 19 & 20 & 17 \\
英国 & 2 & 4 & 3 & 5 & 5 & 5 & 7 & 7 & 5 & 5 \\
カナダ & 3 & 5 & 6 & 5 & 5 & 3 & 3 & 4 & 5 & 4 \\
ニュージーランド & 1 & 1 & 2 & 1 & 3 & 3 & 2 & 3 & 3 & 4 \\
フランス & 1 & 1 & 1 & 0 & 0 & 0 & 2 & 2 & 3 & 5 \\
オーストラリア & 10 & 6 & 3 & 3 & 2 & 2 & 2 & 2 & 2 & 2 \\
南アフリカ & 2 & 2 & 2 & 2 & 1 & 1 & 1 & 1 & 1 & 2 \\
その他 & 216 & 235 & 289 & 280 & 290 & 263 & 280 & 307 & 392 & 530 \\
\hline 総数 & 2,529 & 2,626 & 3,403 & 3,253 & 3,162 & 3,043 & 3,002 & 3,046 & 3,128 & 3,444 \\
\hline
\end{tabular}

出典：統計やいづ 各年版

注：2008年から2009年の大幅増は、旧・大井川町との合併によるもの。

漁業センサス [2013] によると、焼津市は水産加工業に従事する外国人数（市町村別）が 全国一位である $(4,161$ 人中 711 人。うち常時従業者 600 人、その他 111 人)。また、水産加 工業従事者における外国人比率は $17.1 \%$ 、全国平均の $7.1 \%$ をきく上回る。その端緒 を作ったのが、協同組合焼津水産加工センター（1972年設立）であった。同センターは 1990 年からブラジル日系人の共同受入れ事業を開始し、労働者を単身ではなく家族単位 で受入れ、住居を用意して定住を支援した。その後、2001年には同組合が中国人技能実習 生の監理団体となり、加盟企業へ実習生を派遣している [川村 2003]。

\section{2 焼津市の外国人住民に関する先行研究}

焼津市の外国人住民については、静岡文化芸術大学の研究チームが 2000 年代前半に調 査をしている。池上・福岡 [2005］および福岡・池上 [2005］によると、焼津市では 1990 年代から県営B団地で南米系外国人が集住しており、1992年から 2002 年、外国人人口に しめるブラジル人比率は 5 割前後であった。B団地では日本人住民とのトラブルが発生 し、2002年、日本人住民から団地の管理部局に対して外国人増加に伴う生活上の問題を指 摘する「嘆願書」が提出される。静岡文化芸術大学の研究チームが団地住民にアンケート とヒアリングを行っていたのが、ちょうど同年の $10 \sim 11$ 月であった。その後、研究者と市 職員らが仲介をして 2003 年に外国人代表者と自治会役員との会合が開催されたが、次年 度以降は続かなかった。2005年以降は焼津市の外国人住民に関する研究が見当たらない。 


\section{3 市の多文化共生施策}

焼津市の外国人住民施策は以下のとおりである。(1)ウェブサイトの多言語表示。英語、 ポルトガル語、スペイン語、中国、やさしい日本語による表示がある。(2)公民館で日本語 教室（ボランティアが運営）。(3市役所における通訳者の配置。英語、スペイン語、ポル トガル語に加え、2016 年末からタガログ語およびビサヤ語 ${ }^{11)}$ を話す通訳者がいる。(4)広 報やいづ』の多言語版。英語、スペイン語、ポルトガル語がある。(5)多言語生活ガイド ブック。ポルトガル語版、スペイン語版、英語版、中国語版、タガログ語版、ビサヤ語版 が作成されている ${ }^{12)}$ 。なお、外国人集住都市会議には参加していない。

教育施策としては、2017年 5 月現在、市内の小中学校に在籍し日本語指導を必要とする 児童生徒は合計 192 人である ${ }^{13)}$ 。特にその数が多い小学校 2 校では教員の加配があり国際 教室が設置されている。そのほか、教育委員会は 2016 年度から週 2 回、日本語指導が必要 な児童生徒がいる学校へ支援員を派遣している。

\section{4 民間団体}

民間団体による外国人住民への支援は以下のとおりである。第一に、焼津市国際友好交 流協会 (1993 年設立) がある。これは任意団体で、市内の国際交流団体（8 団体）が加盟す るが、市の職員が事務局を兼務しており専任職員はいない。国際交流个ベント「はあとふ る焼津」、国際理解講座、進路ガイダンス、日本語教室の開催が主な活動である。第二 に、隣接する藤枝市の NPO 法人日本インターネット協会がある。この団体は 2009 年から 2014 年に「虹の架け橋事業」を受託して上記のB団地近くで「虹の架け橋教室」を運営し ていた。2014年度で国からの予算が打ち切られた後、2015年は別予算で継続していたが、 2016 年 3 月に焼津市内の教室は完全閉鎖となった。第三に、2014年から市民団体「多文化 共生を考える焼津市民の会・いちご」が学習支援活動を行っている。長期休みに公民館で 「しゅくだいひろば」、土曜日に集住地区の公民館で「放課後ひろば」を開催している ${ }^{14)}$

\section{5 エスニック施設・団体}

市内には 1990 年代から定住しているブラジル人によるエスニックビジネス（人材派遣 業、食料品店、レストラン) のほか、フィリピン人が多いC地区にはフィリピン食材店が ある。また、静岡県浜松市在住のフィリピン日系人が経営する行商のトラックが週 1 度来 る。かつて市内にはブラジル人学校が 2 校あつたがリーマンショック後に閉鎖された。 フィリピン人学校は無い。宗教施設としては市内にカトリック教会が 1 か所、プロテスタ ント系の教会（伝道所を含む）が数か所ある。

1990 年代から焼津市にはフィリピン人の結婚移民がおり、焼津カトリック教会の外国語 ミサに集う。 2000 年代以降のフィリピン人増加に伴い、水産加工業の日系人労働者を中心 に 2016 年 6 月、労働組合が設立された (会員 30 人)。また、 2017 年 9 月に市役所で通訳と 
して働く日系二世の女性を中心に互助団体・焼津フィリピノコミュニティ（会員 140 人） が結成された。

\section{6 人材派遣会社 $A$ 社}

実質的に、焼津市でフィリピン人が増加する原因を作ったのが派遣会社 $\mathrm{A}$ 社である。も ともと運送業を営む $\mathrm{A}$ 社は、アウトソーシング事業部において派遣人材を約 600 人抱えて いる。その内訳はブラジル人 $50 \sim 60$ 人、フィリピン人約 400 人（うち日系人 320 人、新日 系人 $70 \sim 80$ 人)、日本人である。派遣先は水産加工、弁当工場、総菜工場のほか、コンク リート工場や鉄筋組立等で、時給は 900 円（総菜づくり等の軽作業）から 1,500 円（冷凍力 ツオの切断等、危険を伴う作業）まで幅がある。フィリピン人の通訳担当社員が複数名お り、外国人向けの求人広告作成、空港への送迎、市役所や学校等での手続きを行う。

同市のフィリピン人数が約 1,364 人で、労働年齢の人びとを 1,000 人と見積もつたとして も、そのうち 400 人を雇う A 社の存在感は大きい。同社社長（日本人男性、40代後半）に よると、1990年に先代が創業した当初、同社はブラジル、ペルー、アルゼンチンからの労 働者を雇い水産加工および自動車部品製造の工場へ派遣していた。フィリピン日系人を増 やしたのはA社の経営戦略である。定住歴が長い南米系の人びとはA 社に対し賃上げを迫 るが、労働集約的かつ利幅が小さい食品加工業では賃上げをしようにも限度がある。そこ で新規来日者のほうが安い賃金でも働くとみて、A 社は 2003 年頃からフィリピン日系 人、2008年から新日系人に渡航費を貸付けて来日させ、2016年からはフィリピン人技能実 習生も受入れている。

渡航費の貸付は A 社にとってリスクであり利点でもある。返済完了前に労働者が逃亡す るというリスクは常にあるが、義理堅い労働者ならば返済中の 3 年間は $\mathrm{A}$ 社にいてくれ る。A社は派遣人材の数が多いほど売り上げが上がる。貸付金の返済中は同社が借り上げ たアパートに労働者を住まわせ派遣先へバスで送迎する。A社社長は「ブラジル人は問い 合わせの電話をかけてくる時から賃金交渉をして高賃金を求める。だが、フィリピン人は 少なくとも来日当初は従順だ。焼津 (の仕事) は時給が低いので、（自動車関連産業が多 い）浜松等から焼津に引つ越して来て働く人はいない。（同社の渡航費貸付で）フィリピン から直接、焼津に来た人がずっと焼津にいる」と語る ${ }^{15)}$ 。

では、A社にはどのように人材が供給されているのか。そこには日比両国の移民産業が 関わっている。日系人の場合は、上述の日本フィリピン企業協議会がその役割を担う。 1992 年設立にされたこの協議会には現在 27 社が加盟し、A社もその一員である。加盟各社 は協議会を通じて日系人会から渡日希望者の紹介を受ける。加盟会社は食品加工（食鳥加 工、水産加工、弁当・総菜工場）や各種製造業が多い ${ }^{16)}$ 。一方、新日系人はマニラ近郊の 日本語研修所 $\mathrm{F}$ 財団を通じて A 社へ送り出されている。F財団は日本向けの各種人材（経 済連携協定による介護福祉士候補者、家事支援人材、技能実習生等）の渡航前日本語研修 
を請け負つている。同財団職員によると、改正国籍法施行前後の 2008 年から 2009 年にか けては新日系人母子の送出に伴う日本語研修の需要が高まったが (月 10 組前後)、2010年 代半ばになると年に 5 ～ 6 組の送出となつた。現在、A社におけるフィリピン人社員のな かで新日系人の割合は小さいが、F財団にとってはA社が最大の受入れ先だという ${ }^{17)}$

上記のように、焼津市内でフィリピン人が増加した要因は、A 社の渡航費貸付制度を利 用した日系人の来日と就労だと言える。来日後は $\mathrm{A}$ 社のアパートに入居し、役所や学校の 手続きには $\mathrm{A}$ 社の担当者（フィリピン人 /日本人）が同行し、職場も外国人が多い。日本 語を習得しなくても生活し働ける空間が出来上がっているのである。もちろん、労働者は $\mathrm{A}$ 社に対し貸付金を返済した後は転職・転居も可能だが、住夕慣れた焼津市内にとどまり 公営住宅等で暮らして水産加工の仕事を続ける人びとも多い。

\section{7 集住地の形成}

焼津市内の外国人集住地区を示したのが【図 1】である。これは2015年国勢調査の小 地域デー夕をもとに、各小地域の外国人人口により濃淡をつけて作成した地図である ${ }^{18)}$ 。

【図 1】から、外国人人口 100 人以上の地域が 2 か所あることがわかるだろう。ここを集

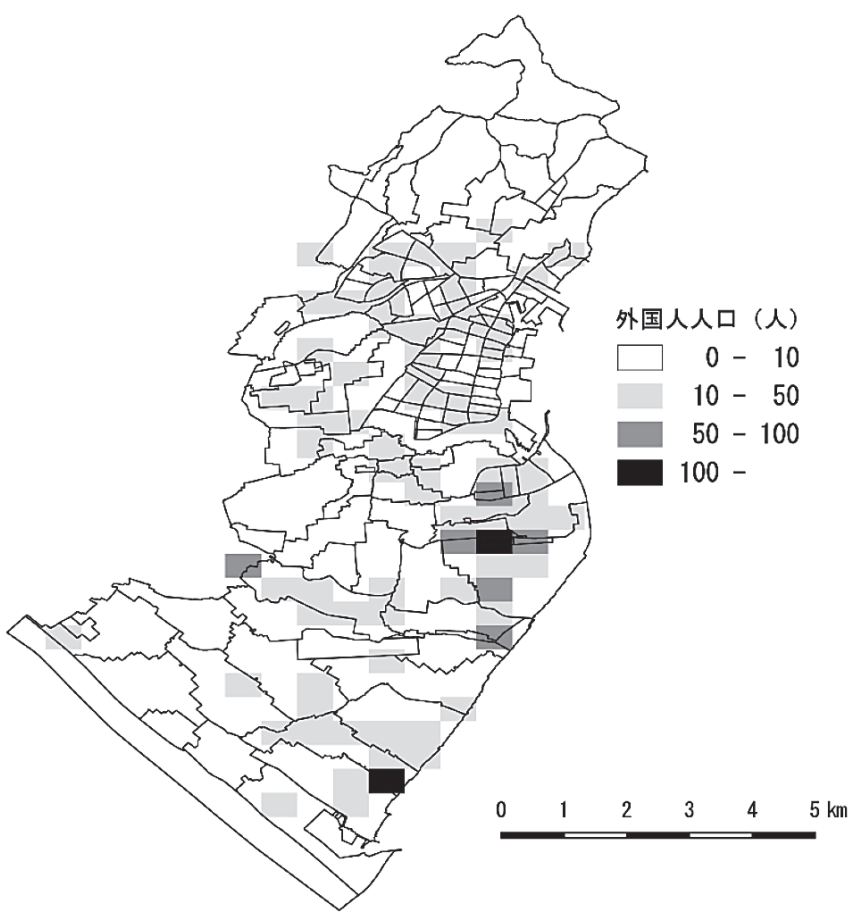

図 1 焼津市内の外国人居住分布

出典：2015年国勢調查、小地域統計 地図作成協力: 水田憲志 
住地区と考えて現地調査をしたところ、以下の諸点が明らかになつた。

第一に、市の中央から南東寄りにあるのが県営 $\mathrm{B}$ 団地である。先行研究でみた池上ほか [2005］の調査地であり、1970年～1972 年および2010年〜2014年に竣工した合計 298 戸の 市内最大の公営住宅である ${ }^{19)}$ 。川村 [2003] および池上ほか [2005］によれば、協同組合焼 津水産加工センターが 1990 年に受け入れたブラジル日系人がこの団地に集住したと理解 するのが妥当だろう。2017年 9 月現在、この団地にはフィリピン日系人も暮らしている が、その数は南米系ほどではない。この団地を学区に含む小学校および中学校では加配教 員がおり国際教室が設置されている。かつて、団地の近くにはブラジル人学校があったが リーマンショック以降は廃校となった。

第二に、市の南端で大井川港に近い C地区である。ここには派遣会社 $\mathrm{A}$ 社が借り上げた 民間アパート 5 棟があり、入居しているのは大半がフィリピン人だ。このアパート入ロや 駐車場等、3〜4か所にA社が作成した大きな貼り紙がある。英語で書かれた貼り紙には 「このアパートは派遣会社Aの管理下にあります。通り抜け、路上のごみ捨ては禁止しま す。違反者は通報します」と書いてある。A社社員によると、アパートには他の派遣会社 やフィリピンパブのリクルーターが頻繁に来るため、彼（女）らに対しての警告文を設置 したという。実際に、筆者が 2017 年 1 月にこのアパートに暮らすフィリピン人母子を訪 ねた時も、駐車場付近にはA社以外の派遣会社のフィリピン人リクルーターが待機してい た。このアパート群から徒歩 3 分の場所にある公民館で、上記の「多文化共生を考える焼 津市民の会・いちご」が毎週土曜日に学習支援活動を行つている。このほか、国勢調查の 小地域単位で外国人 100 人には及ばないものの、フィリピン日系人の親族集団が民間ア パート 1 棟に固まって暮らすなどの形で小規模集住をしている場所がある。

上記の県営 $\mathrm{B}$ 団地も $\mathrm{C}$ 地区も、いずれも沿岸部で海抜 $3 \sim 4$ メートルの、津波の危険が ある場所だ。さらには、交通の便が悪い。JRの駅から車で $10 \sim 15$ 分かかり、バスの本数 は極めて少ない。子どもたちは自転車で 20 分程かけてショッピングセンターに行き、自 動車を持っている親または親族、親の友だち等に乗せてもらい街や教会へ出かける。従っ て、普段の生活は親世代ならば家と職場、子どもたちは家と学校の往復であり、交際範囲 は同じ親族あるいは近隣のフィリピン人に限られがちだ。

\section{6. 知見のまとめ}

ここで冒頭の 4 つの問いに立ち戻り、知見を整理しておきたい。第一に、焼津市におい てフィリピン人が増えた理由は、水産加工業に労働力需要があり、国境を超えて雇用者と 求職者をつなぐ経路ができていたことにある。雇用者は、ブラジル人の減少後に来たアべ ノミクスの影響、および弁当や総菜の需要増に伴い食品加工労働者を必要とした。移住労 働者送出国フィリピンで育った労働者には出稼ぎ志向があり、2000年代に就籍が実現し親 
族単位での連鎖移動が可能となる日系人が増えたことが、日本への押出し要因となった。

第二に、集住地区の形成過程について。従来からの集住地である県営 B 団地に加え、C 地区のように派遣会社が借り上げた民間アパート群が集住地を形成している。移住者が自 由に居住地を選んだ結果というよりは、派遣会社による「作られた集住」である。

第三に、定住への課題におけるフィリピン人結婚移民との差異は、地域住民との接触の 少なさである。結婚移民は個人として日本の家族に加わり、近隣とのつきあいや子どもの PTA等を通じて地域社会へ溶け込んでいった。しかし、日系人は「日本人」と接触せずと も長期滞在でき仕事もできる在留資格である。この状況は南米系日系人と類似する。親族 集団での近隣居住が多いため、そもそも日本人の近隣者と接触する必要がなく、あるとす ればアパートの大家や商店主、派遣会社社員、日本人の同僚くらいである。個人はまず親 族集団に包まれ、そして親族集団は派遣会社に包まれて、日本社会のなかで彼（女）らは 「二重の殼」の中にいる生活をしている。派遣会社が作り出す共同体的空間が、エスニッ クな互助団体に代替するかのようだ。特にC 地区は交通の便が悪い沿岸部にあり、周りは 一戸建てまたは農地である。地域の日本人住民からすれば、外国語を話す集団として彼 （女）らの存在は可視的であろうが、両者は交流する必要性がない。地元住民との交流の 少なさは日系人にとって取り立てて「不満」ではなく、仕事さえあれば新規来住者はやっ てくる。このように「作られた集住」によりセグリゲーションが進んでいる。地域社会と 彼（女）らをつなぐ数少ない回路が、市民団体が毎週土曜日に運営する学習支援活動「放 課後ひろば」で、防災センター (公民館) で開催されており、C地区自治会がその協力団 体に名を連ねている。

第四に、定住への課題におけるブラジル人との差異は教育問題にある。ブラジル人には 民族学校があるが、フィリピン人には無い。在日フィリピン人の第一世代 (1990年代の結 婚移民）が集住地区を形成できなかった上、母国での教員経験者が極めて少なかったこと がその理由であろう。日本で唯一のフィリピン人学校は愛知県にあるが、日比両国から認 可はなく、フィリピン人の子どもたちの幼稚園、あるいは新規来日の子どもが日本の学校 へ入るまでの「つなぎ」の役割を担うのみである [高畑 2014]。

従って、学齢期の途中で来日したフィリピン人の子どもにとって日本の学校が唯一の選 択肢となる。これは金ほか [2015］が報告しているインドネシア日系人の事例と共通す る。それでは、民族学校がなければフィリピン日系人が日本への出稼ぎを躊躇するかとい えばそうではない。多くの出稼ぎ労働者と同様、子どもだけフィリピンの祖母や親族のも とに置いて夫婦で来日したり、子どもも一緒に来日して試行錯誤しながら日本の学校に 通っている。ブラジル人の場合は日本の学校に馴染めなければブラジル人学校に行くとい う選択肢があった。それがないフィリピン人にとっては、小中学校では加配教員または週 2 回派遣される支援員から受ける指導、および週末の「放課後ひろば」が補習の場だが、 不就学や高校進学困難となること子どもたちも散見される。詳細は別稿に記したい。 


\section{7. 結論}

全国有数の水揚げ量を誇る漁港都市の沿岸部にエスニックな空間が固定化されている。 そこでは、派遣会社が作った共同体のなかで生活と労働が完結しており、地元住民との接 触は少なく、学習支援教室が日本社会との数少ない「密口」になっている。この状況は、 1990 年代から南米出身日系人の集住地区で繰り返されてきたことと類似する。1990年代 前半に南米出身の日系人労働者が大量に来日したのが外国人派遣労働者の第一波だとすれ ば、一足遅れで 2000 年代から来たフィリピン日系人にその一部が入れ替わつたことが第 二波だ。彼（女）らが派遣労働市場にいることには変わりがなく、「外国人用」として用意 された労働市場で働き暮らす人びとの顔ぶれが徐々に変わつただけである。

焼津市においては水産加工業の立地および労働条件における不利（交通の便が悪い沿岸 部、自動車産業よりも低賃金）から、より「弱者」となる労働者が求められる。すなわ ち、渡航費という借金を背負い、その返済まで 3 年間は同じ派遣会社で働く必要があり、 新規来日のため他の地域を知らない人びとである。一方、日系人の強みは、属性要因によ り家族単位で定住できることにある。在留資格審査時に学歴や能力で選別されることはな く、結婚移民特有の問題（日本人夫の人柄および社会経済的状態により暮らし向きが大き く変わる）に振り回される必要がなく自活できる。親族集団で近居すれば、フィリピンで 暮らしていた時と同様に子どもを預けあう、食料や金銭や融通しあうなどの相互扶助がで きる。雇用者にとって日系人は「貸付金返済まで一定期間の就労継続が見込め、技能実習 生よりも業種や労働時間において柔軟に使える労働力」であり、労働者にとつて派遣労働 は「初来日時の旅費と職探しを派遣会社が面倒見てくれて、学歴・能力で選別されず働け る職場」と、双方に利がある。

従って、日本での工場労働は、本国の労働市場で競争力がない人びとにとっては良い雇 用機会となる。例えば、低学歴者や農業・漁業労働者、日雇いの建設労働者、零細自営業 者等の不安定就労の人びとにとっては、日本で「時間どおり働けば時間どおりの給与が得 られる」状態は社会経済的上昇となる。換言すれば、日系人を必要とする労働市場には人 的資本に乏しい人びとが集まることになり、今後はそこで働く人びとの階層の固定化、将 来的には福祉的ニーズが出ることも予想できる。これもブラジル日系人の経験と類似する。

本稿は「逆転都市」におけるフィリピン人集住地区形成に伴う地域課題を読み解く作業 の第一歩として、焼津市における集住を地域の産業および雇用の構造から考察する作業で あった。東海地方の外国人といえば自動車産業で働くブラジル日系人の先行研究が蓄積さ れてきたが、本稿ではブラジル人より遅れて同じ労働市場に参入し、不利な立場で働く フィリピン日系人の実態を示すことができた。今後は、フィリピン日系人労働者のインタ ビューに基づき、彼（女）らの来日と定住、労働、子どもの教育等についてより丁寧に描 きたい。また、本稿での知見は他都市でも妥当かを検証することも今後の課題である。 
「逆転都市」の自治体間で、多文化共生施策の充実度、基幹産業の違い（自動車／水産）に よりフィリピン日系人の教育機会、雇用機会、階層的上昇機会はいかに変わるかを明らか にしていきたい。

注

1）2015年 8 月、法務省民事局へのメールによる問合せに基づく。

2）日系人の多い地域はミンダナオ島のダバオ、ルソン島のバギオのほか複数あり、各地で日系 人の生業や階層的位置づけ、出稼ぎ意欲にはばらつきがあるが、本報告では戦前に最大の日系 社会があったダバオの日系社会を中心に論じる。

3） 2017 年 5 月、NPO 法人フィリピン日系人リーガルサポートセンターでの聞き取り。

4）家庭裁判所は、無戸籍者が日本国籍を有しており、かつ戸籍法第 110 条第 1 項に規定する 「本籍を有しない者」と認めれば、就籍許可の審判により新戸籍を編成する。（資料例：写真、 出生証明書、在学証明書) 法務省ウェブサイト

(http://www.moj.go.jp/MINJI/minji04_00047.html\#q2-1２017年 9 月 3 日アクセス）

5）PNLSCウェブサイト（http://www.pnlsc.com/2017年 9 月 3 日アクセス）

6）町村別の国籍別外国人数の公表は 2013 年からのため (それ以前は市区のみ) 静岡県駿東郡清 水町は 2006 年と 2016 年との比較ができず、愛知県美濃加茂市は 2016 年現在でブラジル人と フィリピン人が逆転していないため除外した。なお、浜松市浜北区は 2005 年の市町村合併に より新設されたため 2006 年のデータがなく、比較対象を 2007 年と 2016 年としている。焼津市 は2008年に大井川町と合併しているが統計データに中断はない。

7) この事業 (2009年 4 月から 2010 年 3 月) により合計 21,675 人が帰国し、うち 2 万人余がブラ ジル人であった。厚生労働省ウェブサイト

(http://www.mhlw.go.jp/bunya/koyou/gaikokujin15/kikoku_shien.html２017年11月20日アクセス)

8）『京都新聞』2009年10月4日。

9）『統計やいづ』焼津市ウェブサイト（https://www.city.yaizu.lg.jp/toukei/index.html 2017 年 9 月 3 日アクセス)。

10）中国人は多くが技能実習生、ブラジル人、ペルー人、フィリピン人は日系人等の定住者であ る。統計上は表出しないものの、キリバス人船員が頻繁に一時上陸する (2017年 6 月、水産加 工会社での聞き取り)。キリバスには日本鰹・鮊漁業協同組合連合会の援助で運営される研修 所があり、修了者が日本の遠洋漁船に乗る。遠洋漁業から加工まで、焼津の漁業は外国人労働 者が欠かせない。外務省ウェブサイト

(http://www.mofa.go.jp/mofaj/area/ps_summit/pif_3/kankei.html 2017年 9 月 3 日アクセス)。

11）ビサヤ語はフィリピンの中南部で使われる言語。ミンダナオ島のダバオもビサヤ語圈で、ダ バオ出身の日系人はビサヤ語話者が多いが、タガログ語（引標準フィリピン語）も通じる人が 大半である。

12）焼津市ウェブサイトおよび市民協働課・多文化共生担当者への聞き取り（2017年 9 月）。

13）『静岡新聞』2017年 8 月 10 日。

14） 2014 年 10 月発足。代表者の日本人男性 Dさんは、焼津市南部にある中学校で学校評議員を していた頃、外国人の子どもたちの増加を目の当たりにしたのを契機に支援活動を始めた。当 初から高畑も協力し、学習支援活動へ学生を派遣している。多文化共生を考える焼津市民の 会・いちごウェブサイト (https://yaizu-ichigo.jimdo.com/２017年11月20日アクセス） 
15） 2017 年 2 月、A 社社長にインタビュー。

16）協議会の設立当初は元・引揚者の会社経営者らが、一世の戸籍が見つかつた親族の二・三世 を直接雇用した (2017年 5 月、フィリピン日系人リーガルサポートセンターでの聞き取り)。 従って、日系人を 2000 年代初めから雇う A 社は後発組と言える。

17） 2017 年 8 月、マニラ首都圏郊外にある F 財団事務所でインタビュー。

18）焼津市の外国人居住地図は2015年国勢調査の小地域データから作っている。ただし、国勢 調査の回収率は $100 \%$ ではないこと、居住者の国籍別デー夕は存在しないため「フィリピン人 が多い小地域」の地図は作成不可能であることを断つておく。

19）静岡県住宅供給公社ウェブサイト

(http://www.sjkk.or.jp/kenei/pdf/annaisho_h28.pdf２017年10月15日アクセス)

\section{参考文献}

福岡欣治・池上重弘，2005，「多文化化する公営住宅における居住者の意識：焼津市 T団地の事 例分析」『静岡文化芸術大学研究紀要』5:61-78.

Fresnoza-Flot, Asuncion. 2008. "Labor Migration and Minority Group Empowerment: The Nikkeijin in Davao and Their Association.” Asian Studies Journal, 44 (1): 66-102.

Gammeltoft-Hansen, Thomas and Ninna Nyberg Sorensen (eds.), 2013, The Migration Industry and the Commercialization of International Migration, New York: Routledge.

早瀬晋三，1989，『ベンゲット移民の虚像と実像：近代日本・東南アジア関係史の一考察』同文 館.

樋口直人，2011，「経済危機と在日南米系コミュニティ一何をなすべきか」『Business Labor Trend』11-15.

飯島真里子・大野 俊, 2010,「フィリピン日系『帰還』移民の生活・市民権・アイデンティティ 一質問票による全国実態調査結果 (概要) を中心に」『九州大学アジア総合政策センター紀 要』 $4: 35-54$.

池上重弘・福岡欣治, 2005, 「外国人居住者は地域コミュニティの担い手となり得るか? 一焼津 市T団地での調査から」『静岡文化芸術大学研究紀要』5:1-12.

石川義孝・竹下修子・花岡和聖，2014，「2005-2010年における新規流入移動と国内移動からみ た外国人の目的地選択」『京都大学文学部研究紀要』53:293-318.

加瀬和俊, 2005 , 「漁業・水産加工業における外国人労働者問題についての一考察」『漁業経済学 会ディスカッションペーパー』1:20-24.

川村浩之, 2003, 『我組合の労務対策事業と研修生共同受入事業, 教育情報事業の活動事例につ

いて』(一社) 商工総合研究所・中小企業組織活動懸賞レポート平成 15 年度本賞受賞作品.

金 延景・栗林 慶・川口志のぶ・包 慧穎・池田真利子・山下清海, 2016, 「茨城県大洗町に おける日系インドネシア人の定住化要因 : 水産加工業における外国人労働者の受け入れ変 遷の分析を中心に」『地域研究年報』38:31-59.

国際移住機関 (IOM)，2015，『「定住外国人の子どもの就学支援事業」(虹の架け橋事業）成果報 告書』国際移住機関.

増井好男, 2012, 「水産加工業の展開とその振興施策」一般財団法人東京水産振興会編『構造再 編下の水産加工業の現状と課題一平成 23 年度事業報告一』15-29.

大野 俊, 1991,『ハポン：フィリピン日系人の終わらない戦後』第三書館. 
，2006，「『ダバオ国』の沖縄人社会再考一本土日本人，フィリピン人との関係を中心

に」『移民研究』 $2: 1-22$.

， 2007,「フィリピン日系人の市民権とアイデンティティの変遷一戦前期の二世誕生か ら近年の日本国籍く回復 > 運動まで」『移民研究年報』13:79-97.

Ohno, Shun, 2015, Transforming Nikkeijin Identity and Citizenship: Untold Life Histories of Japanese Migrants and their Descendants in the Philippines, 1903-2013. Quezon City: Ateneo de Manila University Press.

高畑 幸，2013，「日本人移民の子孫と国際婚外子一フィリピンから『帰還』する新旧日系人」 蘭信三編著『帝国以後の人の移動一ポストコロニアリズムとグローバリズムの交錯点』勉 誠出版, 935-968.

—, 2014 , 「日本で唯一のフィリピン人学校一その役割の変遷を中心に」『ことばと社会』 16: $247-254$.

—, 2016 , 「浜松市におけるフィリピン人コミュニティの現状と課題一日系人の増加を中 心に」『国際関係・比較文化研究』14(2): 191-203.

Vilog, Ron Bridget, 2014, "Remembering the Great Ancestors: Images of Japanese Emigrants from the Perspective of Third- and Fourth-Generation Philippine Nikkeijin in Japan”, Asian Studies: Journal of Critical Perspectives on Asia, 50 (2): 39-73.

渡戸一郎， 2017，「『編入モード』から見る日系ブラジル人の位置と第二世代の課題」渡戸一郎編 集代表, 塩原良和・長谷部美佳・明石純一・宣元錫編『変容する国際移住のリアリティー 「編入モード」の社会学』ハーベスト社, 114-136.

\section{付記}

本報告は科研費助成（基盤 $\mathrm{C}$, 課題番号 $16 \mathrm{~K} 04082$, 「東海地方における外国人労働者の『逆転 現象』〜ブラジル人からフィリピン人へ」代表・高畑幸）を利用した研究成果の一部である。

(たかはた さち/静岡県立大学准教授) (原稿受付 2017 年 11 月 30 日、掲載決定 2018 年 3 月 19 日) 